\title{
Optimization of religious extension role in COVID-19 pandemic
}

\author{
Hasan Bastomi* \\ Institut Agama Islam Negeri Kudus, Kudus, Indonesia \\ Email: hasan@iainkudus.ac.id
}

\begin{abstract}
Purpose - This study aims to investigate the optimization of the role of religious instructors in the midst of the COVID-19 pandemic.

Method - This research is a type of library research, namely, by recording all findings and integrating all findings, both theories and new findings about the religious extension, analyzing all findings from various reading and providing critical ideas about optimizing the role of religious instructors in the midst of the COVID-19 pandemic.

Result - The results of the study show that various issues in all sectors emerged as a result of the outbreak of the COVID-19 pandemic, it is necessary to optimize the role of religious instructors who play a very strategic role in the framework of mental, moral, and value development devotion of the people and also contribute to improving the quality of life of the people in various fields both in the field of religion and development amid COVID-19 pandemic by carrying out informative and educative functions, consultative functions, and advocacy functions.

Implications - To optimize the role, several things need to be done by religious instructors.

Originality - The framework of mental development with optimization of religious extension role in the midst of COVID-19 pandemic.
\end{abstract}

Keywords: Religious extension, pandemic, COVID-19.

For citation: Bastomi, H. (2020). Optimization of religious extension role in COVID-19 pandemic. Journal of Advanced Guidance and Counseling. 1(2). 157-179. https://doi.org/10.21580/jagc.2020.1.2.6032.

*Corresponding author: Hasan Bastomi (hasan@iainkudus.ac.id), Institut Agama Islam Negeri Kudus, Gondangmanis No.51, Ngembal Rejo, Ngembalrejo, Kec. Bae, Kabupaten Kudus, Jawa Tengah 59322. 
Hasan Bastomi

JAGC $\mid 158$

\begin{abstract}
Abstrak
Tujuan - Penelitian ini bertujuan untuk mengetahui optimalisasi peran ustadz di tengah pandemi COVID-19.

Metode - Penelitian ini merupakan jenis penelitian pustaka yaitu dengan mencatat semua temuan dan mengintegrasikan semua temuan baik teori maupun temuan baru tentang penyuluhan agama, menganalisis semua temuan dari berbagai bacaan dan memberikan gagasan kritis tentang optimalisasi peran penyuluh agama di tengah-tengah. dari pandemi COVID-19. Hasil - Hasil penelitian menunjukkan bahwa berbagai permasalahan di semua
sektor muncul sebagai akibat dari merebaknya pandemi COVID-19, maka
diperlukan optimalisasi peran ustadz yang berperan sangat strategis dalam
kerangka mental, moral, dan pengembangan nilai pengabdian kepada
masyarakat serta berkontribusi pada peningkatan kualitas hidup masyarakat di
berbagai bidang baik di bidang keagamaan maupun pembangunan di tengah
pandemi COVID-19 dengan menjalankan fungsi informatif dan edukatif, fungsi
konsultatif, dan fungsiadvokasi.
\end{abstract}

Implikasi-Untukmengoptimalkan peran tersebut, beberapa hal perlu dilakukan oleh para penyuluh agama.

Originalitas - Kerangka pembinaan mental dengan optimalisasi peran penyuluh agama di tengah pandemi COVID-19.

Kata kunci: Penyuluh agama, pandemi, COVID-19.

\title{
Introduction
}

By the end of 2019, the world was shocked by the spread of the coronavirus known as COVID-19. The virus was first discovered endemic in Wuhan city, Hubei province, China. The virus is thought to be derived from bats as its host that devolves to bat-eating humans. In addition to this opinion, some say that COVID19 is a mutation of the SARS virus that was also first discovered in China in 2002, which quickly spread to various countries, and has not yet become a pandemic. The virus was also reported missing in 2004.

The virus is not completely lost, even in its incubation period the virus can be contagious in humans. In addition, the virus can move to others through the hands of healthy people who hold hands, or various items affected by the sick person's virus, through his cough splash. Human hands and fingers become media for the virus to enter the human body. So far according to experts, the virus does not move through the air (Indriya, 2020). 
Recorded until dated March 25, 2020, 414,179 confirmed cases reported with 18,440 deaths (CFR 4.4\%) cases are reported in 192 countries/regions. Among these cases, there have been several health workers who have reported being infected. On March 2, 2020, Indonesia reported 2 COVID-19 confirmation cases. As of March 25, 2020, Indonesia has reported 790 COVID-19 confirmation cases from 24 provinces, namely: Bali, Banten, DIY, DKI Jakarta, Jambi, West Java, Central Java, East Java, West Kalimantan, East Kalimantan, Central Kalimantan, South Kalimantan, Kep. Riau, West Nusa Tenggara, South Sumatra, North Sumatra, North Sulawesi, Southeast Sulawesi, South Sulawesi, Lampung, Riau, North Maluku, Maluku, and Papua. Areas with local transmission in Indonesia are DKI Jakarta, Banten (Kab. Tangerang, Tangerang City), West Java (Bandung City, Bekasi City, Bekasi City, Depok City, Kab. Bogor, Kab. Bogor, Kab. Karawang), East Java (Kab. Malang, Kab. Magetan and Surabaya) and Central Java (Surakarta City) (Kemenkes \& $P 2 P, 2020)$.

Various problems in all sectors are raised as a result of the COVID-1659 pandemic. The impact of COVID-19 on the field of economic impacts on the difficulty in finding jobs, meeting the needs of daily life, having no income in meeting the needs for every day and also a lot of distress received from all sectors economy the felt the impact of COVID-19 (Hanoatubun, 2020). In the field of law, according to Mahfud MD the impact is very noticeable which is increasingly significant general criminality in some areas, caused by the pandemic situation that cripples the economy. It is seen from the report of local authorities, the criminality that occurs mostly with the motive of theft. Whereas in the social field if we observe the news circulating lately, there are interesting social facts that occur in the community. An interesting fact is that there are prejudice and discrimination against victims of COVID-19. This prejudice and discrimination are caused by people's fear of uncertain situations due to the spread of the coronavirus. This COVID-19 case not only causes social disorganization but also causes social dysfunction. Social dysfunction occurs when a person is unable to perform social functions that correspond to social status due to fear of COVID-19. A real example of social dysfunction can be seen in people's attitudes that start to limit the distance 
Hasan Bastomi

from others and do not want to help others because they are worried about being exposed to COVID-19.

This social dysfunction causes the individual to become impaired in his health. From a health sociology perspective, a person is called healthy if physical, mental, spiritual, or social conditions can make the individual perform his or her social functions. But if the condition is disturbed then the person is declared sick. In the case of COVID-19, the pain in question is socially ill. According to Talcott Parsons in his book "The Social System", pain is not only a biological condition but also a social role that does not function properly. Parsons sees pain as a form of deviant behavior in society because the sick person cannot fulfill his or her social role normally. It is this disorganization and social dysfunction that is a tangible manifestation of social pain. In addition, COVID-19 pandemic also impacts the mental health of the community in the form of psychological anxiety or depression, as many as 64.3 percent of the 1,522 respondents had psychological problems of anxiety or depression after conducting a self-check online related to the mental health impact of the COVID-19 pandemic conducted on the official page of the Indonesian Society of Mental Medicine Specialists (PDSKJ).

Symptoms of anxiety and depression felt are excessive fear and worry, feeling unable to relax and comfortable, having sleep disturbances, and excessive alertness. Of the 1,522 respondence, the data gained that there were the most anxiety symptoms in women of 76.1 percent with a minimum age of 14 years and a maximum of 71 years (Aziz, 2020). With various problems due to the COVID-19 pandemic, the Indonesian government is working to restore conditions, one of which is by providing incentives as a stimulus for the community. But what is done by the government is not enough, it needs participation from various parties one of which is the extension of religion.

Based on research conducted by Hidayat (2019) that Islamic Extension has a quite strategic role in the community. In addition to as an Islamic preacher, he also played the role of Counselor of Islam, according to his function as a mentor, illuminator, and community builder with religious language. The role of religious counselors in addition to serving as a community driver to actively participate in development also participates in overcoming the obstacles that build the 
development path, especially overcoming the negative impact of development. Religious counselors as religious leaders always guide, protect, and move the community to do good and avoid forbidden deeds, inviting to something that is the need of its people in building its territory both for societal facilities and worship. Religious Counselor becomes a place of questioning and a place to complain about his community to solve and finish with his advice. Religious Counselor also serves as a community leader acting as a priest in religious matters and societal problem as well as in-state affairs with efforts to make a government program. One form of religious extension role is to improve and create the quality of sakinah family that exists in the group of assembly ta'lim Al Muhajirin Sukarame II Teluk Betung Barat Sub-District Bandar Lampung City.

The Ministry of Religious Affairs also plays a role in conveying Islamic preaching. As research conducted by Limbong (2018) that the counselor of the Ministry of Religious Affairs played a role in conveying Islamic preaching in The Umbrella District of Karo Regency who still believes and follows the tradition of Karo customs is done by respecting Karo tradition and customs.

Religious Counselor also played a role in the improvement of the implementation of prayer fardhu community as to where research conducted by Najmuddin (2018) that counseling activities given by religious counselors to the community are very important in improving the implementation of fardhu prayer in Ngaringan district of Grobogan Regency.

Based on the Decree of the Minister of Religion (KMA) No. 79 of 1985 religious counselors have three functions that are often called trilogy namely informative educational functions, consultative functions, and advocacy functions (Departemen Agama RI, 1985), then the role of religious counselors is highly expected in the COVID-19 pandemic as it is today with various problems in various sectors. Therefore the problem is how to optimize the role of religious counselors during the COVID-19 pandemic. 
Hasan Bastomi

\section{Research Method}

This research includes a type of literature research (library research), that is, by recording all the findings and combining all the findings of either theory or new findings of the role of religious counselors during the COVID-19 pandemic, analyzing all the findings from various readings and providing critical ideas about the optimization of the role of religious counselors during the COVID-19 pandemic. The focus of research that researchers take is the optimization of the role of religious counselors during the COVID-19 pandemic. This is based on the importance of the role of religious counselors in the midst of the COVID-19 pandemic for the community.

\section{Results and Discussion}

\section{Impact of COVID-19 Pandemic for People}

Since COVID-19 cases have increased in Indonesia, various problems have arisen in the community, ranging from social, economic, legal, and psychological problems to society. As a result, the Indonesian government began to carry out various policies such as issuing the appeal of social distancing, issuing calls for Work From Home for employees, imposing regional restrictions, building special hospitals for the handling of COVID-19, and others. With the policies of this government and the increasingly precarious situation, it certainly has an impact on society, both the middle and lower classes to the elite. Various socio-economic problems arise and the immediate impact is felt by society. The more socioeconomic problems caused by COVID-19 the more visible to the public. Some of the socio-economic problems that caused by COVID-19 include:

a. Scarcity of goods

The increase in the number of COVID-19 victims which continues to increase in Indonesia resulting in some goods becoming scarce on the market. Not only rare, but these items were sold for many times from their original price before the Corona happens in Indonesia. Some items that are becoming scarce include masks, hand-sanitizers, disinfectants, and PPE. These goods are now being sold at a much higher price than their original price. This is in accordance with economic law where 
when the demand increases but the goods are getting low, the price will increase. Even people with middle and upper economic conditions have a tendency to buy up these goods so that there is an accumulation of goods but for the middle to lower class people they cannot get them.

Not only for personal protective equipment, but people also flock to buy basic necessities in large quantities, along with the issue of lockdown in Indonesia. Hoarding of goods as a result of something emergency is called panic buying. Executive Director Institute for Development of Economics and Finance (INDEF) Enny Sri Hartanti said that panic buying behavior was caused by psychological factors resulting from imperfect or comprehensive information received by the community. This lack of information caused people to panic, so they responded by spending massively to save themselves. Public concern is that they are worried that prices will rise if they don't shop immediately and worry that the goods will run out soon.

b. Social disorganization and dysfunction

Whereas in the social field if we observe the news circulating lately, there are interesting social facts that occur in the community. An interesting fact is that there are prejudice and discrimination against victims of COVID-19. This prejudice and discrimination are caused by people's fear of uncertain situations due to the spread of coronavirus. This can be seen clearly from the attitude of the community who keeps their distance when interacting with others, avoids shaking hands, avoids gatherings, and so on. This attitude of society originates from prejudice which leads to discriminatory attitudes. This prejudice and discrimination are a manifestation and social disorganization.

Social dysfunction occurs when a person is unable to perform social functions that correspond to social status due to fear of COVID-19. A real example of social dysfunction can be seen in people's attitudes that start to limit the distance from others and do not want to help others because they are worried about being exposed to COVID-19. One example is the community in the Sawangan area, Depok City, rejecting the use of public cemeteries in their area for the graves of COVID-19 victims. The public is very worried if the buried corpse can still spread the 
Hasan Bastomi

Coronavirus in their area. Even though a corpse that has been properly processed in the hospital using various protectors such as disinfectants and special crates will not cause the spread of the Coronavirus.

JAGC | 164

This social dysfunction causes the individual to become impaired in his health. From a health sociology perspective, a person is called healthy if physical, mental, spiritual, or social conditions can make the individual perform his or her social functions. But if the condition is disturbed then the person is declared sick. In the case of COVID-19, the pain in question is socially ill. According to Parsons in his book "The Social System", pain is not only a biological condition but also a social role that does not function properly. Parsons sees pain as a form of deviant behavior in society because the sick person cannot fulfill his or her social role normally. It is this disorganization and social dysfunction that is a tangible manifestation of social pain.

\section{c. Action criminal}

It is also feared that the COVID-19 problem will have an impact on increasing criminal activity. The criminal acts carried out can be various, such as theft of personal protective equipment which is currently scarce, making fake handsanitizers or disinfectants that actually endanger health, fraud in the price of basic commodities, and others. One example is the case of a civil servant in Cianjur who was caught stealing 20,000 masks. Other larger crimes such as robbery, murder, looting, might have occurred if the situation got out of hand.

d. The weakening of the tourism sector

The tourism sector is one of the sectors that contribute greatly to regional income and to increase employment for the community. This tourism sector is related to hotels, restaurants, tourist attractions, and others. However, since the COVID-19 case has increased, various tourist spots must be closed for an undetermined time to prevent the spread of Corona. With the closure of various tourist attractions, it will automatically affect regional income and especially community income. For regions that rely on the tourism sector as the largest contributor to regional income, they must be aware of the decline in regional income due to the closure of tourist attractions. In addition, the closure of tourist 
attractions also affects workers who also rely on income from the tourism sector, especially informal sector workers whose income is irregular.

e. Poverty and unemployment rates increase

Poverty is defined as a condition in which a person is not able to maintain JAGC | 165 himself according to the standard of life of the group and is also unable to utilize his energy, mentally, and physically in the group (Sukanto, 2013). The Corona case in Indonesia has almost paralyzed people's economic activities. Since the government implemented various policies such as Work From Home, territorial restrictions, and the closure of various public places such as tourist attractions, many companies or offices have closed their employees. Some UMKM entrepreneurs have even whitened their employees (PHK) in anticipation of the impact of business closures in an undetermined time.

Not only that, but informal sector workers are also very disadvantaged due to this Corona case. Informal workers who usually get daily income now find it difficult to meet their needs. They are shop workers, small shops, hawkers, market traders, online motorcycle taxi drivers, to other workers who depend on their daily income, including in shopping centers. As a result, they chose to return to their hometown because they were unable to bear the burdens of life without certainty of income. During the last eight days, there were 876 inter-provincial bus fleets carrying approximately 14,000 passengers from Jabodetabek to West Java, Central Java, East Java, and Yogyakarta. Most of them are informal workers who earn their living in the capital city (BBC Indonesia, 2020).

The impact of the further corona case, caused the poverty and unemployment rates in Indonesia to increase. As of March 2019, it was recorded that the population of vulnerable groups of poor and near-poor in Indonesia had reached 66.7 million people or almost three times the number of people below the poverty line (the poor and very poor). Ironically most of this group work in the informal sector, especially those who rely on daily wages. If the handling of a pandemic lasts for a long time, the period of limitation and decrease in the mobility of people will be even longer. As a result, the vulnerable to poor and near-poor who work in the 
Hasan Bastomi

informal sector and rely on daily wages will very easily lose their livelihoods and fall below the poverty line (CNBC Indonesia, 2020).

With these various socio-economic problems, the Indonesian government is trying to restore conditions, one of which is by providing incentives as a stimulus for the community. Minister of Finance Sri Mulyani Indrawati said that the government is preparing an economic stimulus volume III which will focus on the health sector and reach out to social networks. This flow of aid will be channeled through government programs such as the family hope program, people's business credit, ultra-micro credit, basic food cards, and non-cash food assistance programs (BBC Indonesia, 2020). However, the government also needs not only to pay attention to the welfare of the community in economic terms, but the government must also pay attention to the social and psychological side of the community. This is because social welfare is not only about meeting economic needs, but also social and psychological needs in the form of peace and security for the community. One of them is by continuing to limit false information (hoaxes) that can disturb the public and provide information that can provide enthusiasm and positive energy for the community. Thus, the welfare of the Indonesian people, whether affected by Corona or not, will remain guaranteed until the Corona case is resolved.

\section{The Role of Religious Instructor}

Judging from the scope of social organization, the role is a component in the organizational system, in addition to organizational norms and culture. The role is a dynamic aspect in the form of an action or behavior carried out by a person who occupies or holds a position in exercising rights and obligations according to his position. If someone carries out this role well, he will naturally hope that what is carried out according to the wishes of the environment. Sociologically, the role is the dynamization of the status or use of rights and obligations, or it can also be called subjective. This is in line with Soekamto's opinion that role is a dynamic aspect of position (status). If a person exercises his rights and obligations in accordance with his position, then he will carry out a role (Tangkilisan, 2005).

Role theory (role theory) suggests that a role is a set of behaviors associated with a certain position. Different roles create different types of behavior. But what 
makes the behavior appropriate in one situation and inappropriate in other situations is relatively free for someone who plays the role (Sukanto, 2013).

One of the da'wah systems that are quite familiar in the community and implemented by government agencies (Ministry of Religion) and religious organizations is the dakwah activity called counseling. This activity plays an important role in increasing the religious awareness of the community, providing a torch of light on procedures (kaifiyat) both related to issues of increasing the quality of worship and delivering information related to religious life development programs.

Islamic counseling is quite urgent in its position as a form of developing Islamic da'wah practice. Academically at the Faculty of Da'wah and Communication, Islamic Counseling is not only a subject, but it is one of the nomenclatures of the study program or the name of the department at the Faculty of Da'wah, complete with Islamic Guidance and Counseling (abbreviated as BPI) (Enjang, 2009).

Extension is derived from the word "suluh" which means "torch" or "which gives light". The extension is expected to increase knowledge, skills, and attitudes. Meanwhile, formulating a definition of religion is part of the problem of studying religion scientifically. The many definitions of religion actually obscure what we really want to understand about religion. There are four patterns in defining religion through root word patterns, paradigm descriptions, and developing patterns (Ghazali, 2004).

Islamic religious instructors who are given full duties, responsibilities, and rights by authorized officials to carry out Islamic guidance or counseling activities on "issues of faith (aqidah), issues of Islam (syari'ah) and problems of character (akhlakul karimah) (Pranowo, 2002)". The term religious instructor began to be socialized in 1985, namely with the decree of the minister of religion Number 791 of 1985 regarding honoraria for religious instructors. If we trace it from history, the origin of the religious extension profession comes from the Honorary Religion Teacher (GAH). The term religious instructor is used to replace the term Honorary Religion Teacher (GAH) previously used within the Ministry of Religion Officials. 
Hasan Bastomi

Since its inception, the Religious Instructor has been the spearhead of the Ministry of Religion in implementing Islamic religious information amid the rapid dynamics of the development of Indonesian society. Its role is very strategic in the JAGC | 168 context of developing mental, moral, and devout values of the people and contributing to improving the quality of life of the people in various fields, both in the religious and development fields. Islamic Religious Instructors are guides for religious people in the context of mental, moral, and devotion to God Almighty, and Islamic Religious Instructors, namely mentors of Muslims in the context of mental, moral, and devotion to God Almighty, Allah SWT, and describing everything. aspects of development through doors and religious language.

The task of Islamic extension agents is currently dealing with a rapidly changing social condition that leads to a functional society, a technological society, a scientific society, and an open society. Thus, every religious extension worker needs to continuously improve his knowledge, insight, and self-development, and also needs to understand the vision of the religious extension agent and to optimally master the material of religious education itself and the technique of conveying it. So that there is a factual correlation to people's needs at their every move and step.

A religious extension is an activity carried out by religious instructors in providing guidance and delivering da'wah messages to mad'u. Religious extension workers are Civil Servants who are given full duties, responsibilities, and authority by the authorized official to carry out religious guidance and development education activities through religious language. The agency for facilitating the extension of religion is the Ministry of Religion.

Religious extension workers have a target group or community members who are in a religious extension work area. The group has been formed in an organized group of at least 10 to 20 people and has a directed and systematic coaching program. Religious instructors are in a unit that has a specific religious substance which is regulated by a decree of the Ministry of Religion. For example, in Sukadanaham Village, there are special extension officers who play an active role in driving community education activities in guidance. Extension of religion and 
development through religious language and organizational activities, dakwah institutions, religions in their working area (Dapartemen Agama RI, 2007).

The task of the instructor is not merely to carry out religious counseling in the narrow sense in the form of recitation, but the entire information activity in the form of guidance and information on various development programs. He acts as a guide for the people with a sense of responsibility, bringing people to a safe and prosperous life. The position of this Islamic extension agent is very strategic both to convey religious missions and development missions.

The religious extension has objectives that are differentiated between shortterm and long-term goals. The short-term objective of religious counseling is to foster more directed changes in both the awareness and religious activities of the community (people). The changes referred to are in the form of knowledge, attitudes, and motives (intentions), and behavior. The change in knowledge is meant to include what the community (ummah) should know about various aspects of the teachings, both issues of aqidah, shari'ah, and muamalah (Faith, Islam, and Ihksan). Changes in the field of attitude that are meant include changes in thoughts and feelings. Meanwhile, in the field of motive (intention), the intended actions include what they actually do and what they do in their daily lives, rests on sincere intentions so that all forms of action have value and become worship.

Meanwhile, the long-term goal of religious counseling is to build a society based on Islamic ideals, which fulfills several minimum principles in it, such as basic Islamic principles regarding family, social, political, and economic. The model of the ummah or society that is to be realized can be seen as an ideal model of Islamic society that has long been awaited. A society with its system of beliefs and concepts, with its traditions and systems of worship, with its religious thoughts and tastes, with its morality and noble values, with its legal and statutory system, with its economy and wealth, by means of recreation and the art.

The long-term goal of the religious instructor referred to not only to put forward a theoretical structure of society according to Islam but to reveal some of the characteristics or aspirations of an Islamic society formula. This formulation is expected to become one people or society that reflects Islam as the teachings of 
Hasan Bastomi

pure monotheism, strong faith, useful knowledge, righteous deeds, high morality, advising each other in kindness and patience, helping each other in kindness and piety, and working hard to achieve an ideal, invite goodness and prevent evil and believe in Allah to get the title as the best people and become the choice of mankind (Enjang, 2009).

Therefore, in addition to sufficient skill, religious extension agents must have mastery of both extension materials and delivery techniques. The religious counselor must also be able to decide and determine a process of guidance and counseling activities so that it can run systematically, be effective, efficient in achieving the desired goals. There are several roles and duties of the Honorary Religious Instructor, namely: (1) Religious instructors act as community guides, (2) Religious instructors act as role models, (3) Religious instructors act as a connector for religious information tasks, (4) Religious instructors also play a role in development, (5) Hold religious lectures or wirid weekly, (6) Teaching reading and writing of the Koran, (7) Helping to change people's behavior for the better, (8) Organizing religious activities that involve the entire community as activities in it, (9) Organizing regular recitation, in the form of programs annual, monthly, and weekly, (10) As a figure, role model or figure modeled by the community, (11) Providing direction in increasing religious faith and harmony, and, (12) Participation in successful development (Hidayat, 2019).

Based on the Decree of the Minister of Religion (KMA) Number 79 of 1985, religious extension agents have three functions which are often called a trilogy, namely an informative educational function, a consultative function, and an advocacy function (Jaya, 2017). In terms of function and role have almost the same definition. The role is defined as a device of behavior that is expected to be owned by a person domiciled in society, while the function is defined as a position (job) that is carried out (Departemen Pendidikan Nasional, 2008). 


\section{Optimizing the role of religious instructors in the realm of the COVID-19}

The role of religious instructors in the midst of the COVID-19 pandemic was applied in the implementation of the functions of religious extension workers, namely informative and educational functions, consultative functions, and advocacy functions. First, the informative and educational function of the Islamic extension agent is able to position him as a preacher in a broad sense who is obliged to preach Islam. The informative and educational function is the work of fostering, giving lessons, giving religious messages according to the Qur'an and AlSunnah (Jaya, 2017) as well as providing information and education about the prevention of the COVID-19 outbreak by providing information and education about the COVID-19 virus to the public about the prevention of the COVID virus, namely by recognizing in detail anything related to COVID-19 through information from doctors, medical teams, and experts by doing four simple things, namely: wearing a mask when leaving the house, washing your hands with soap in running water every time you start and end an activity, and the latter always maintaining (social distancing) and always increasing the body's immunity by exercising, maintaining a pattern and consuming vitamins. Don't let religious extension workers act counterproductively with government policies.

In the New Normal era, now, religious extension workers are expected to provide a correct understanding to the public regarding the meaning of "new normal". "Currently, many people consider the behavior of new normal to be the same as the behavior before the COVID-19 pandemic. People do activities without paying attention to health protocols. Even though the emphasis is on activities with new behaviors, namely wearing masks, washing hands, and maintaining social distancing in order to make peace with COVID-19.

In a religious aspect, as a religious instructor, he invites the people to get closer to God Almighty, by not being too afraid but also not underestimating him. When religion is connected with the activities of its people, there is something in it which is called worship. Worship is the most basic thing in every religion. However, with the current coronavirus, religious activities are disrupted, then it can also interfere with religious activities. Because of the virus, every community is not allowed to 
Hasan Bastomi

gather with many people. Even though not a few in every religion have rituals of worship which are carried out directly and simultaneously by involving many people in one place of worship. So, religious extension workers must provide education and information to the public to carry out religious activities in their respective homes to prevent the spread of COVID-19 among the community.

In carrying out its role of providing information and education to the community, religious extension agents are very important to strengthen guidance and outreach to the community both directly and through social media in providing outreach, education, and innovation, especially dealing with dire situations such as the current COVID-19 pandemic. So it is hoped that the public will be wiser in absorbing all information in accordance with the facts.

Second, the consultative function: religious extension workers provide themselves to think about and solve problems faced by society, either individually or in groups (Jaya, 2017). In addition to providing consultation services on the dangers of COVID-19 and how to overcome it, religious extension agents can also play a role in providing psychological consultations to the community in the midst of the COVID-19 pandemic.

The Ministry of Health (Kemenkes) said the Coronavirus (COVID-19) had a significant impact on people's lives. COVID-19 is said to cause mental health problems. Whereas actually those affected are not only COVID, positive, PDP and ODP patients but healthy people can also be affected and also vulnerable groups including health workers, this vulnerable group includes several groups such as elderly children under five including adolescents then also several other groups including groups of people who have mental disorders. So the impact of COVID is very broad and can cause mental health problems.

Currently, the world community is facing COVID-19 pandemic. As more and more people hear or watch obituaries in several countries, people are affected psychologically. They are physically healthy but feel anxious so that they are psychologically disturbed. Whereas anxiety can have a contagious effect, especially if what you hear or watch is mostly negative things, so it is possible that you cannot control your life properly. When anxiety occurs, it causes stress which over time 
erodes the physical condition. When the physical condition decreases, the body's immunity may also decrease. If immunity decreases, it is not impossible for the coronavirus which we call COVID-19 to enter the body.

There is a relationship between physical and psychological health that affects each other, so there is psychosomatic or somatization disorder. This happens JAGC | 173 because of disturbing psychic or irrational thoughts, for example, some people feel sick even though when checked by a doctor there is no disease whatsoever. If people are stressed and don't have a good way to manage stress, this is very disturbing.

These uncertain conditions will make people more stressed, so religious extension workers are expected to provide consultation through counseling and psychological services to the public in order to limit negative news, especially those related to COVID-19. It is advised that every time in life not always listen to or watch it, because there is a lot of news that is not balanced between negative and positive, including the circulation of hoax news.

Consultation services carried out by Religious Turks are planned to be able to provide an understanding that whatever is happening right now must be God's will. The lesson from the government's appeal regarding COVID-19 for Work From Home (WFH) or with a campaign with the hashtag "\#dirumahaja", is meeting the whole family, the husband with wife and children so that we can interact more. The teaching to always keep clean can also be echoed because in Islam cleanliness is part of faith, something that is sometimes underestimated. So that there is selfawareness, concern for self-understanding, no longer being selfish in maintaining a healthy body. In addition to staying at home and continuing to maintain social distance in the real world, with religious extension consultancy services it is also hoped that people will think positively, always be happy in today's life. Always be grateful so that you are good psychologically so that the body is not easily infected by viruses, and if you are already exposed or are still under surveillance, it will accelerate the situation for the better.

Third, the advocacy function: religious extension workers have a moral and social responsibility to carry out activities to defend the people or community 
Hasan Bastomi

JAGC | 174

against various threats, disturbances, obstacles, and challenges. The advocative function can also be interpreted as carrying out activities of defense, community assistance from all forms of activities that will destroy faith and religious rules/order. The third one is, for example, what happened in the case of refusing the body of COVID-19.

With the rise of cases of community rejection of the bodies who died as a result of COVID-19, religious counselors are expected to ask the public to respect and accept the burial of the bodies of patients who have contracted the coronavirus or COVID-19 by providing advocacy to the community so that they can accept and respect and organize their funeral - rejection because every Muslim must understand that burial bodies are a religious order, rejection of the corpse of COVID-19 is due to the fact that the public is starting to feel tension because of the existence of COVID-19 and ignorance of the transmission of COVID-19.

If you look at the work of religious instructors in the midst of the COVID-19 pandemic, the informative educational function is more dominant than the other two functions. This dominant role can be understood because the history of GAH is a form of information work in society. Although it needs to be noted critically, that the function of the GAH at first was only to provide information to the people there was no local dai. GAH is specifically functioned to provide religious information to community groups who have not been touched by dai in general, such as preaching in prisons or various social institutions. However, if you look at the practice of most of the current religious extension workers, most of them work as extension workers in their respective recitation communities or attend invitations to the religious formation from recitation groups and the community. (Does GAH not exist yet ??)

Educative information / informative preaching in the general public has basically been done a lot by local preachers, preachers from various Islamic organizations or many have been preached from television and social media online which are easily accessible to the public. Thus, if the religious counselor only plays the function as a lighting da'wah, then his gait does not mean much. If religious counselors still want to play informative functions then the function that can be done is to play a role that has not been done by local dai in general, such as 
doing management, organizing, coaching against all dai in the community, or the development of content and contemporary media, such as lighting filmmaking, advertising services, or various other forms of dawah on social media related to the repetition of COVID-19.

Reflections on the optimization of the role of religious counselors have so far JAGC | 175 shown that consultative and advocacy functions get a smaller share of educational informative functions, whereas the two roles are very important and urgent given the social problems in society in times of COVID-19 pandemic is increasingly complex. The consultative function is the role of religious counselors to provide solutions to problems faced by people, especially providing guidance and counseling on the problems of life that people experience (problem solver) during the COVID-19 pandemic. Meanwhile, the function of advocacy is to defend by visiting neighborhoods in need, such as mentoring people who reject COVID-19 or who have a negative stigma about COVID-19 sufferers so that they can carry out daily (normal) activities. Religious counselors can also play a development function, namely optimizing the local potentials that people have in the midst of the COVID19 pandemic so that it can be economically valuable (Jaya, 2017).

To optimize the role of counselors, the extension must be a popular profession in the community at the time of the COVID-19 pandemic. The paradigm of extension work should no longer be a paradigm "work in silence" or "silent trail", because "working in silence" makes this profession suspected of "sleep", does not contribute to the construction of (Dapartemen Agama Rl, 2007). Thus the counselor is required to perform the role of a "super hero" that exists when needed by the community so that the role of extension is missed by the community. There needs to be a revitalization of the target of the counselors, from tabligh to be an escort to solve the problem of society (problem base) in the midst of the COVID-19 pandemic. Counselors need to make monumental work in solving social problems during pandemic COVID-19 in Indonesia. Nevertheless, the ultimate goal of mentoring remains principled on the goal of community development namely selfreliance or helping people to help themselves in the midst of the COVID-19 pandemic. 
Hasan Bastomi

In the method of social intervention not only known problem-based paradigm (problem-based) but also there is a paradigm of potential-based development (asset-based community development). Both have their own advantages and JAGC | 176 disadvantages so that in each location (sub-district) counselors can take both approaches. The difference between problem-based and asset-based lies from the point of view of looking at things. The problem-based approach sees something as a problem, while the asset-based approach sees something as potential (Kretzmann, \& McKnight, 1993). For example, when people see COVID-19 sufferers, some see it as a problem because it is feared to transmit to other communities. Whereas COVID-19 sufferers must be accompanied to constantly improve the immune system and recover immediately, quarantined families also feel comfortable because they have the support of the community.

The dominant educational activities of educational awareness about COVID19 unemployment have so far been conducted not based on problems or potential, but as routine activities. Actions born because of habits and routines (traditional action) does not give birth to reflection and significant changes for the community related to the unemployment of COVID-19. When viewed from the guidelines of birth, actually the traces of potential-based approaches have begun to be seen because every year the activity of birth starts with asset logging, in the form of the number of mosques and jama'ah, but many do so to the extent of completing the initial procedure of the year that is not used as the basis of the program reference so that the activities carried out are the same as the previous years (monotonous).

To get the ideal support activity related to COVID-19 disturb, every birthing activity starts by making a plan. Planning can start from the problem of what the community or client faces (can be prevention or problem solving). From the case, a planning design was created that contained the stages and time for achieving the goal. During this time the lecture activities conducted were not intended to solve a problem, there was not even a blueprint (planning) of the program so its success was never measured. Whereas there is an old saying (Benjamin Franklin) that says if you fail to plan, you are planning to file (Jaya, 2017). 


\section{Conclusion}

From some of the previous descriptions can be expressed the following: the first, various problems in all sectors raised as a result of the COVID-19 pandemic, therefore, the optimization of the role of religious counselors who have a role is very strategic in the framework of mental development, moral and the value of people's ketaqwaan (God-consciousness) as well as encouraging the improvement of the quality of life of people in various fields both in the field of religion and development in the midst of the COVID-19 pandemic.

Secondly, The role of religious counselors during the COVID-19 pandemic is applied in the implementation of religious counseling functions, informative and educational functions in the form of information and education related to the transmission and prevention of COVID-19, consultative functions in the form of providing psychological consulting services to the community, and advocacy functions in the form of enforcement of the rights of people affected by negative stigma caused by COVID-19.

Third, to optimize the role of religious counselors then the extension should be a popular profession in society in the midst of COVID-19, in conducting social intervention during COVID-19 religious extension not only using problem-based paradigm (problem-based) but also paradigm development based on potential (asset-based community development), in carrying out the role of religious counselors performing informative functions, consultative and supportive with a balanced portion, given the social problems in the community during the COVID19 pandemic is increasingly complex, To get the ideal birth activity, every activity of support begins by making planning.

\section{References}

Aziz, A. (2020). "Survei: 64,3\% dari 1.522 orang cemas \& depresi karena COVID-19" dalam tirto.id edisi 1 Mei 2020 diakses dari https://tirto.id/survei-643dari-1522-orang-cemas-depresi-karena-COVID-19-fgPG

BBC Indonesia, 30 Maret 2020. Virus corona: Peta dan infografis terkait pasien terinfeksi, meninggal dan sembuh di Indonesia dan dunia. Diakses dari https://www.bbc.com/indonesia/indonesia-51850113 
Hasan Bastomi

BBC Indonesia, 30 Maret 2020. Virus corona: Pendapatan usaha kecil 'pupus' akibat COVID-19, pemerintah siapkan bantuan sosial untuk pekerja harian. Diakses dari https://www.bbc.com/indonesia/indonesia-52059235

JAGC | 178

CNBC Indonesia, 29 Maret 2020. Karena corona, ekonomi RI diprediksi -2\%. Diakses dari https://www.cnbcindonesia.com/market/20200329113617-17148245/karena-corona-ekonomi-ri-diprediksi-2

Dapartemen Agama RI. (2007). Panduan tugas penyuluh agama masyarakat. Direktorat Jendral Bimbingan Masyarakat Islam.

Departemen Pendidikan Nasional. (2008). Kamus besar bahasa Indonesia Pusat Bahasa (4th ed.). Gramedia Pustaka Utama.

Enjang, A. S. (2009). Dasar-dasar penyuluhan Islam. Ilmu Dakwah: Academic Journal for Homiletic Studies, 4(14), 727-764. DOI: https://doi.org/10.15575/idajhs.v4i14.419

Ghazali, A. M. (2004). Agama dan keberagaman dalam kontek perbandingan agama. Pustaka Setia.

Hanoatubun, S. (2020). Dampak COVID - 19 terhadap perekonomian Indonesia. EduPsyCouns: Journal of Education, Psychology and Counseling, 2(1), 146153.

Hidayat, R. (2019). Peran penyuluh agama dalam kehidupan beragama guna meningkatkan keluarga sakinah (study kasus pada majelis ta'lim AlMuhajirin Sukarame li Bandar Lampung). Mau'idhoh Hasanah: Jurnal Dakwah Dan Ilmu Komunikasi, 1(1). 92-108.

Indriya, I. (2020). Konsep tafakkur dalam alquran dalam menyikapi coronavirus COVID-19. SALAM: Jurnal Sosial Dan Budaya Syar-i, 7(3). https://doi.org/10.15408/sjsbs.v7i3.15050

Jaya, P. H. I. (2017). Revitalisasi peran penyuluh agama dalam fungsinya sebagai konselor dan pendamping masyarakat. KONSELING RELIGI: Jurnal Bimbingan Konseling Islam, 8(2).

Kemenkes RI, \& P2P. (2020). Pedoman pencegahan dan pengendalian coronavirus disesase (COVID-19). Kemenkes RI \& Direktorat Jenderal Pencegahan dan Pengendalian Penyakit (P2P).

Kretzmann, John. P., \& McKnight, J. L. (1993). Building communities from the inside out: $A$ path toward finding and mobilizing a community's assets. Acta Publications. 
Limbong, M. (2018). Peran penyuluh Kementerian Agama dalam menyampaikan dakwah Islam di kecamatan Payung kabupaten Karo [Skripsi]. Universitas Islamnegeri Sumatera Utara Medan.

Najmuddin, I. (2018). Peran penyuluh agama Islam dalam peningkatan pelaksanaan shalat fardhu masyarakat di kecamatan Ngaringan kabupaten Grobogan [Skripsi]. Fakultas Dakwah Dan Komunikasi Universitas Islam Negeri Walisongo Semarang.

Pranowo, B. (2002). Pedoman penyuluhan. Departemen Agama RI.

Sukanto, S. (2013). Sosiologi: Suatu pengantar. Raja Grafindo Persada.

Tangkilisan, H. N. S. (2005). Manajemen publik. Gramedia Pustaka Utama. 